\title{
Fluctuations of the population of Daphnia laevis Birge 1878: a six-year study in a tropical lake
}

\author{
Brandão, LPM. ${ }^{a *}$, Fajardo, T. ${ }^{a}$, Eskinazi-Sant'Anna, E. ${ }^{b}$, Brito, S. ${ }^{a}$ and Maia-Barbosa, . $^{a}$ \\ a'Laboratório de Ecologia do Zooplâncton, Instituto de Ciências Biológicas, \\ Universidade Federal de Minas Gerais - UFMG, Av. Antônio Carlos, 6627, CP 486, CEP 30161-970, \\ Belo Horizonte, MG, Brazil \\ 'Laboratório de Ecologia Aquática, Instituto de Ciências Exatas e Biológicas, Universidade Federal de Ouro Preto - UFOP, \\ Campus Morro do Cruzeiro, s/n, Bauxita, CEP 35400-000, Ouro Preto, MG Brazil \\ *e-mail: lucianapmb@hotmail.com
}

Received July 5, 2011 - Accepted October 24, 2011 - Distributed August 31, 2012

(With 6 figures)

\begin{abstract}
The fluctuation of the population of Daphnia laevis in Lake Jacaré (Middle River Doce, Minas Gerais) was monitored monthly (at one point in the limnetic region) for six years (2002-2007) as part of the Program of Long-Term Ecological Research (LTER/UFMG). The following parameters were also monitored: water temperature, $\mathrm{pH}$, electrical conductivity, dissolved oxygen, chlorophyll a, total phosphorus, phosphate, total nitrogen, nitrate, nitrite, ammonia, and densities of Chaoborus and ephippia of Daphnia laevis in the sediment. A seasonal pattern was observed in the fluctuation of D. laevis, with higher densities recorded during periods of circulation (May-August). A significant correlation was found between the density of $D$. laevis and temperature $(\mathrm{r}=-0.47, \mathrm{p}=0.0001)$, chlorophyll- $a(\mathrm{r}=-0.32, \mathrm{p}=0.016)$ and indicators of the lake's trophic status (total phosphorus, $r=0.32, p=0.007$ and trophic state, $r=0.36, p=0.003$ ), as well as Chaoborus density $(\mathrm{r}=0.43$ and $\mathrm{p}=0.002)$. These results indicate that changes in the physical and chemical characteristics of the water related with stratification and circulation of the lake may have a direct (temperature, total phosphorous) or an indirect (food availability, presence of predators, ephippia eclosion) influence on the fluctuation of the D. laevis population.
\end{abstract}

Keywords: Daphnia laevis, Brazil, tropical lake, temperature, ephippium.

\section{Flutuações da população de Daphnia laevis Birge 1878: seis anos de estudo em um lago tropical}

\begin{abstract}
Resumo
A flutuação da população de Daphnia laevis na Lagoa Jacaré (Médio Rio Doce, Minas Gerais) foi monitorada mensalmente, em um ponto na região limnética, por seis anos (2002 a 2007), como parte do Programa de Pesquisas Ecológicas de Longa Duração (PELD/UFMG). Os seguintes parâmetros foram monitorados: temperatura da água, $\mathrm{pH}$, condutividade elétrica, oxigênio dissolvido, clorofila- $a$, fósforo total, fosfato, nitrogênio total, nitrato, nitrito, amônia e densidades de Chaoborus e de efípios de Daphnia laevis no sedimento. Um padrão sazonal foi observado na flutuação de $D$. laevis, com maiores densidades registradas durante períodos de circulação (maio a agosto). Correlações significativas foram observadas entre a densidade de D. laevis e a temperatura $(\mathrm{r}=-0.47, \mathrm{p}=0.0001)$ e a clorofila- $a(\mathrm{r}=-0.32, \mathrm{p}=0.016)$, e indicadores do estado trófico do lago (fósforo total, $\mathrm{r}=0.32, \mathrm{p}=0.007$ e estado trófico, $\mathrm{r}=0.36, \mathrm{p}=0.003$ ), além de densidade de Chaoborus $(\mathrm{r}=0.43, \mathrm{p}=0.002)$. Esses resultados indicam que mudanças nas características físicas e químicas da água relacionadas com os periodos de estratificação e circulação do lago podem influenciar diretamente (temperatura, fósforo total) ou indiretamente (disponibilidade de alimento, presença de predadores, eclosão de efípios) a flutuação da população de D. laevis.
\end{abstract}

Palavras-chave: Daphnia laevis, Brasil, lago tropical, temperatura, efípio. 


\section{Introduction}

Zooplankters are short life-cycle organisms that are sensitive to environmental variations (Fryer, 1996; Crispim and Watanabe, 2000). Whereas some species are extremely vulnerable to any disturbance, others are more tolerant and even opportunistic. The Branchiopoda group has some highly successful forms which, due to their small size, rapid reproduction (mainly by parthenogenesis) and efficient feeding mechanism, are able to occupy a wide range of freshwater habitats, including those where they are subject to high predation pressure (Lynch, 1980). The ability to produce dormant stages increases the possibility of this group's ecological success (Fryer, 1996). Due to the short life cycle, rapid reproduction and sensitivity to alteration in the environment, the population densities of these organisms vary throughout the year, usually showing seasonal patterns (Williams, 1982).

Environmental conditions (such as temperature, dissolved oxygen, $\mathrm{pH}$, and others) are important factors that act directly on the structure of the zooplankton community, changing the spatial and temporal distribution of the species (Bottrell, 1975; Vijverberg et al., 1996; Gyllström et al., 2004). Furthermore, biotic factors, such as predation (Brooks and Dodson, 1965; Rocha et al., 1990), competition (Smith and Cooper, 1982), food availability and quality, within others, have an enormous pressure on the populations.

It has been shown that temperature is the most important factor affecting the structure of zooplankton communities of lakes in the temperate region (Calaban and Makarewicxz, 1982; Benndorf et al., 2001; Gerten and Adrian, 2002; Schalau et al., 2008). In the tropics, despite the small annual temperature fluctuations, population responses can be observed (Bunioto and Arcifa, 2007). This variable can influence zooplankton in two ways: directly, on the reproduction rates, filtration rates, duration of the life cycle, production and hatching of resistance eggs (Rocha et al., 1990; Crispim and Watanabe, 2000; Bunioto and Arcifa, 2007); or indirectly, through thermal stratification. This phenomenon creates a larger spatial heterogeneity, also causing a "zooplankton stratification", where the organisms group according to the best environment conditions or because they cannot overcome the physical-chemical barriers (Thackeray et al., 2006). Despite the importance of temperature for zooplankton, studies on the influence of these specific parameters on these communities in tropical environments are still scarce.

Organisms of the genus Daphnia are frequently found in continental aquatic ecosystems. It is known that these organisms feed on algae, detritus and bacteria (EskinaziSant'Anna et al., 2002; Pinto-Coelho et al., 2003) and that they reproduce by parthenogenesis and/or sexuated reproduction by means of the formation of dormant eggs known as ephippia (Fryer, 1996). Daphnia is also a predation target for the planktivorous fish and aquatic invertebrates. Since it is a genus with a well-known ecology, it is also used for toxicology tests and as bioindicators (Barros et al.,
2007). Mergeay et al. (2006) analyzed the distribution and abundance of the genus Daphnia in 40 environments located in the tropical region. According to these authors, the success of Daphnia and other zooplankton species was related to the trophic state, altitude, temperature, macrophyte presence and level of predation by fish.

Besides the importance of studies on population dynamics to understand the functioning of aquatic ecosystems, knowledge concerning the responses of tropical organisms for biotic and abiotic factors is essential to support ecological hypothesis, which are mainly based on data from temperate lakes (Mergeay et al., 2006; Bunioto and Arcifa, 2007). Thus, the present study contributes with information on long-term fluctuations of the population of Daphnia laevis Birge, 1878 in a tropical lake, monitored monthly for six years.

This study considered the hypothesis that population peaks of this species throughout six years of monitoring could be explained by changes in the lake's physical and chemical characteristics during circulation periods. The aim of this study was to analyze which environmental parameters influenced the population dynamics of Daphnia laevis in Lake Jacaré during the study period.

\section{Material and Methods}

\subsection{Study area}

Lake Jacaré (area: 103.09 ha, depth: 9.8 m, $271 \mathrm{~m}$ altitude, $19^{\circ} 48^{\prime} 38.8^{\prime \prime} \mathrm{S}$ and $42^{\circ} 38^{\prime} 55.5^{\prime} \mathrm{W}$ ) is located near the middle River Doce, next to the Parque Estadual do Rio Doce (PERD), Minas Gerais, Brazil (as shown in Figure 1). The climate in the region is hot, with annual mean temperatures between 20 and $22{ }^{\circ} \mathrm{C}$. The lake has

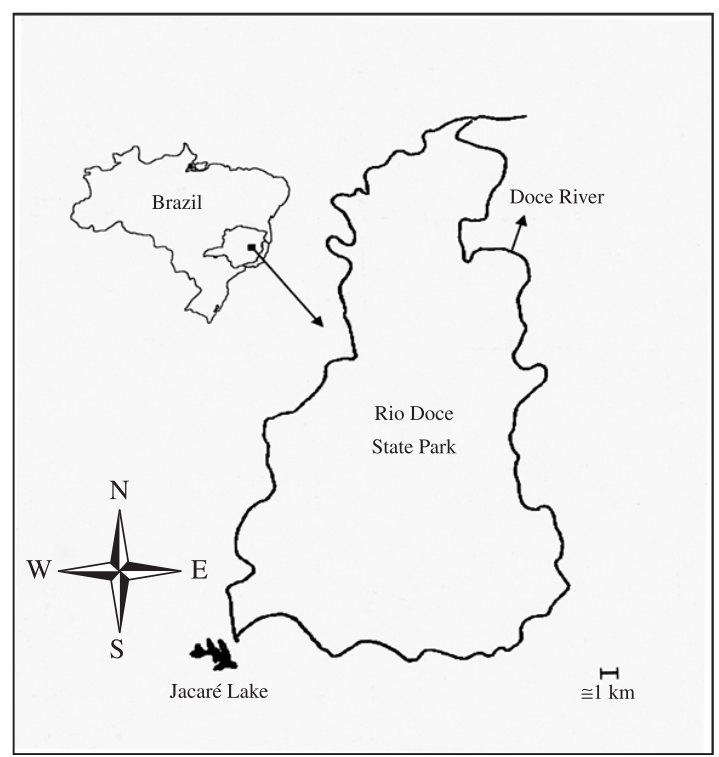

Figure 1. Lake Jacaré (Middle River Doce, Minas Gerais- Brazil). 
a dendritic shape and is a warm-monomictic lake with a circulation period from May to August. It is surrounded by plantations of Eucalyptus sp., it shelters a fishing club with a camping area and receives domestic sewage. Furthermore, the ichthyofauna was drastically altered after the introduction of exotic fish species for sport fishing during the 1970s: the Tucunare Cichla kelberi, Piranha Pygocentrus nattereri, African catfish Clarias gariepinus, Tamoatá Hoplosternum littorale and Amazon Acará Astronotus ocellatus (Latini et al., 2004). These introductions probably had direct and indirect effects on the zooplankton community, as reported for another lake from the same system (Maia-Barbosa et al., 2003a). This lake has been monitored by the Brazilian Long Term Ecological Research (LTER/UFMG), firstly with seasonal samples (2000 and 2001) and, from 2002 to 2008 , with monthly samples.

\subsection{Environmental variables}

Profiles of water temperature $\left({ }^{\circ} \mathrm{C}\right), \mathrm{pH}$, electrical conductivity $\left(\mu \mathrm{S} . \mathrm{cm}^{-1}\right)$ and concentration of dissolved oxygen (mg.L $\left.{ }^{-1}\right)$ were made with a Horiba (model U-22) analyzer.

Water samples were collected with a Van Dorn bottle from four depths determined by the Secchi disc in order to determine the concentrations of chlorophyll- $a$ (Lorenzen, 1967), total phosphorus, phosphorus, total nitrogen, nitrate, nitrite and ammonia, according to Mackereth et al. (1978).

The lake's trophic state was calculated by the geometric average of the concentrations of total phosphorus, according to the index proposed by Salas and Martino (1991), based on data collected from January, 2002 to July, 2007.

\subsection{Zooplankton community}

Samples were collected monthly between 2002 and 2007 at a fixed point of the limnetic region, in the four depths defined by the Secchi disc. For the quantitative analysis, $200 \mathrm{~L}$ of water was filtered (approximately $13 \mathrm{~L} / \mathrm{min}$ ) (Stihl motorized pump, model P835) in a plankton net with $68 \mu \mathrm{m}$ mesh size. The qualitative samples were obtained by horizontal and vertical towing using the same net. The material was fixed with $4 \%$ buffered formaldehyde and stained with Rose Bengal and the counts (zooplankton and Chaoborus sp.) were made under an optical microscope in a Sedgwick-Rafter chamber. At least three subsamples of $1 \mathrm{~mL}$ were analyzed, or until a total of 200 individuals of the dominant species. The results (expressed as org. $\mathrm{m}^{-3}$.) are presented as the means of the monthly values, from the four depths, recorded between 2002 and 2007.

Sediment samples were also collected in triplicate, in October and December 2007 (rainy period), with a core sampler, in order to assess the presence of ephippia of D. laevis. All the collected material was placed in dark refrigerated flasks (approximately $5^{\circ} \mathrm{C}$ ) until processing. To separate the eggs from the sediment, the samples were homogenized in a sugar-distilled water solution (1:1) (Onbé, 1978; Marcus, 1990) and centrifuged at 3,600 rpm for 5 minutes. The material retained on the net was washed with distilled water and kept refrigerated $\left(5^{\circ} \mathrm{C}\right)$ in labeled flasks (Crispim and Watanabe, 2000; Maia-Barbosa et al., 2003b). The ephippia were analyzed and counted under a stereoscopic microscope.

\subsection{Statistical analysis}

The possible influence of the environmental parameters ( $\mathrm{pH}$, temperature, dissolved oxygen, electrical conductivity, nutrients, trophic state) and chlorophyll- $a$ on the D. laevis population was evaluated by Spearman correlations, using the program Statistica 7.0 (Statsoft).

In order to evaluate if the differences in D. laevis' densities in the dry and rainy seasons were statistically significant, the Mann-Whitney test (Statistica 7.0) was used. For the Mann-Whitney test (see Figure 4), the monthly values of the densities versus sampling depth were used. The mean densities were used on the graph to represent the variations in D. laevis densities between the dry and rainy seasons.

\section{Results}

\subsection{Environmental variables}

Lake Jacaré was thermally stratified from September to April (rainy season), with a short period of circulation from May to August (dry season) (Figure 2). Higher temperatures were observed during the stratification period, ranging from 20.0 to $33.1^{\circ} \mathrm{C}$ (mean $27.5^{\circ} \mathrm{C}$ ), and lower during the circulation period (mean $24.3^{\circ} \mathrm{C}$ ).

The secchi disc ranged from 1.0 to $4.5 \mathrm{~m}$, dissolved oxygen from $0.01 \mathrm{mg} . \mathrm{L}^{-1}$ in the hypolimnion to $8.5 \mathrm{mg} . \mathrm{L}^{-1}$ in the epilimnion (mean $3.9 \mathrm{mg} . \mathrm{L}^{-1}$ ), and the $\mathrm{pH}$ values ranged from 5.0 to 7.7 (mean 6.4). The lowest values were recorded in the greatest depths. Electrical conductivity ranged from 34.6 to $303.9 \mu \mathrm{S} . \mathrm{cm}^{-1}$ (maximum value in July 2003) with a mean of $64.1 \mu \mathrm{S} . \mathrm{cm}^{-1}$. The highest values were recorded in the greatest depth, during the circulation period. According to the index of Salas and Martino (1991), Lake Jacaré was almost always oligo-mesotrophic, except for two periods (April to August 2002, and July and August 2004) (Figure 3). Concentrations of nutrients and chlorophyll- $a$ from rainy and dry periods are shown in Table 1. Clorofila- $a$ ranged from 7.39 to $137.43 \mu \mathrm{L}$ (mean 27.68), with the higher values occurring during the stratification period.

\subsection{Daphnia laevis and Chaoborus population}

The mean population density of $D$. laevis varied from 0 to 10790 org. $\mathrm{m}^{-3}$ during the period. Higher densities were recorded during the circulation periods (dry season, May to August) and lower mean temperatures (maximum 10790 org. $\mathrm{m}^{-3}$ ). During the periods of thermal stratification, lower densities were observed (minimum 0 and maximum 3600 org. $\mathrm{m}^{-3}$ ) (Figure 4).

Significant Spearman correlations were found between the density of $D$. laevis and certain environmental variables, such as: negative correlation with temperature $(r=-0.47$ and 


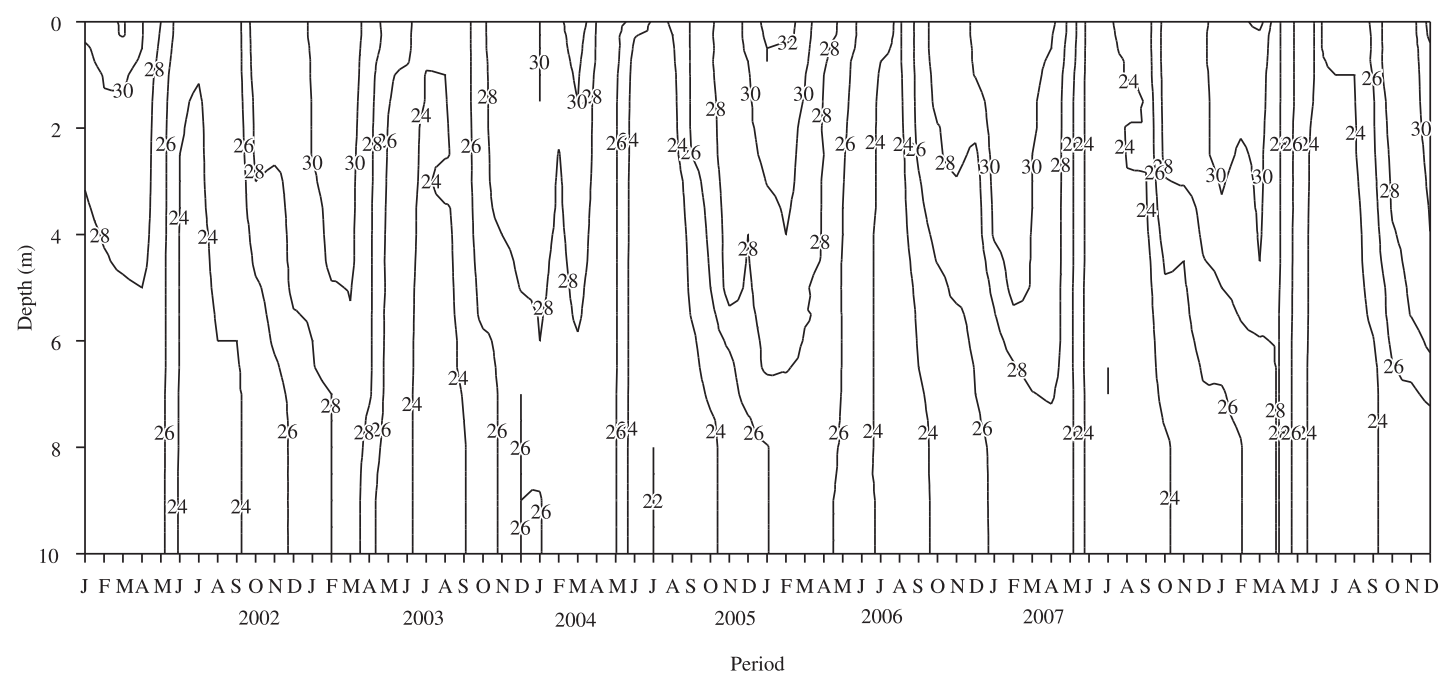

Figure 2. Depth-time diagrams of temperature, at intervals of $2{ }^{\circ} \mathrm{C}$, in the lake from 2002 to 2007 .

Table 1. Values of nutrients and chlorophyll in the stratification and circulation periods.

\begin{tabular}{|c|c|c|c|}
\hline \multicolumn{4}{|c|}{ Stratification periods } \\
\hline & Minimum & Maximum & Mean \\
\hline Chaoborus (org. $\mathrm{m}^{-3}$ ) & 0.0 & 4050.0 & 884.0 \\
\hline $\mathrm{pH}$ & 5.0 & 8.0 & 6.4 \\
\hline Electrical conductivity $\left(\mu \mathrm{S} . \mathrm{cm}^{-1}\right)$ & 0.1 & 352.7 & 68.7 \\
\hline Dissolved oxygen (mg. $\mathrm{L}^{-1}$ ) & 2.2 & 13.5 & 7.2 \\
\hline Temperature $\left({ }^{\circ} \mathrm{C}\right)$ & 24.5 & 30.6 & 28.1 \\
\hline Chlorophyll- $a\left(\mu \mathrm{g} . \mathrm{L}^{-1}\right)$ & 7.9 & 137.4 & 34.6 \\
\hline Total phosphorus $\left(\mu \mathrm{g} . \mathrm{L}^{-1}\right)$ & 9.0 & 103.9 & 27.8 \\
\hline Phosphate $\left(\mu \mathrm{g} . \mathrm{L}^{-1}\right)$ & 1.3 & 27.6 & 5.6 \\
\hline Total nitrogen $\left(\mu \mathrm{g} . \mathrm{L}^{-1}\right)$ & 218.3 & 1258.6 & 565.2 \\
\hline $\mathrm{NH} 4\left(\mu \mathrm{g} . \mathrm{L}^{-1}\right)$ & 7.2 & 664.8 & 200.3 \\
\hline $\mathrm{NO} 3\left(\mu \mathrm{g} \cdot \mathrm{L}^{-1}\right)$ & 0.8 & 25.8 & 8.9 \\
\hline $\mathrm{NO} 2\left(\mu \mathrm{g} . \mathrm{L}^{-1}\right)$ & 0.4 & 9.0 & 3.2 \\
\hline Trophic state & 8.8 & 74.6 & 25.1 \\
\hline \multicolumn{4}{|c|}{ Circulation periods } \\
\hline & Minimum & Maximum & Mean \\
\hline Chaoborus (org. $\mathrm{m}^{-3}$ ) & 0.0 & 3550.0 & 857.3 \\
\hline $\mathrm{pH}$ & 4.8 & 34.7 & 7.5 \\
\hline Electrical conductivity $\left(\mu \mathrm{S} . \mathrm{cm}^{-1}\right)$ & 4.3 & 223.6 & 46.8 \\
\hline Dissolved oxygen (mg. $\mathrm{L}^{-1}$ ) & 4.5 & 19.6 & 9.7 \\
\hline Temperature $\left({ }^{\circ} \mathrm{C}\right)$ & 22.5 & 28.9 & 24.7 \\
\hline Chlorophyll- $a\left(\mu \mathrm{g} \cdot \mathrm{L}^{-1}\right)$ & 7.4 & 26.7 & 16.0 \\
\hline Total phosphorus $\left(\mu \mathrm{g} . \mathrm{L}^{-1}\right)$ & 6.2 & 98.8 & 33.6 \\
\hline Phosphate $\left(\mu \mathrm{g} . \mathrm{L}^{-1}\right)$ & 0.3 & 352.4 & 18.7 \\
\hline Total nitrogen $\left(\mu \mathrm{g} . \mathrm{L}^{-1}\right)$ & 176.6 & 992.8 & 465.9 \\
\hline $\mathrm{NH} 4\left(\mu \mathrm{g} . \mathrm{L}^{-1}\right)$ & 38.1 & 374.5 & 153.0 \\
\hline $\mathrm{NO} 3\left(\mu \mathrm{g} . \mathrm{L}^{-1}\right)$ & 3.5 & 59.0 & 17.7 \\
\hline $\mathrm{NO} 2\left(\mu \mathrm{g} . \mathrm{L}^{-1}\right)$ & 1.1 & 4.7 & 2.2 \\
\hline Trophic state & 6.4 & 93.8 & 33.0 \\
\hline
\end{tabular}




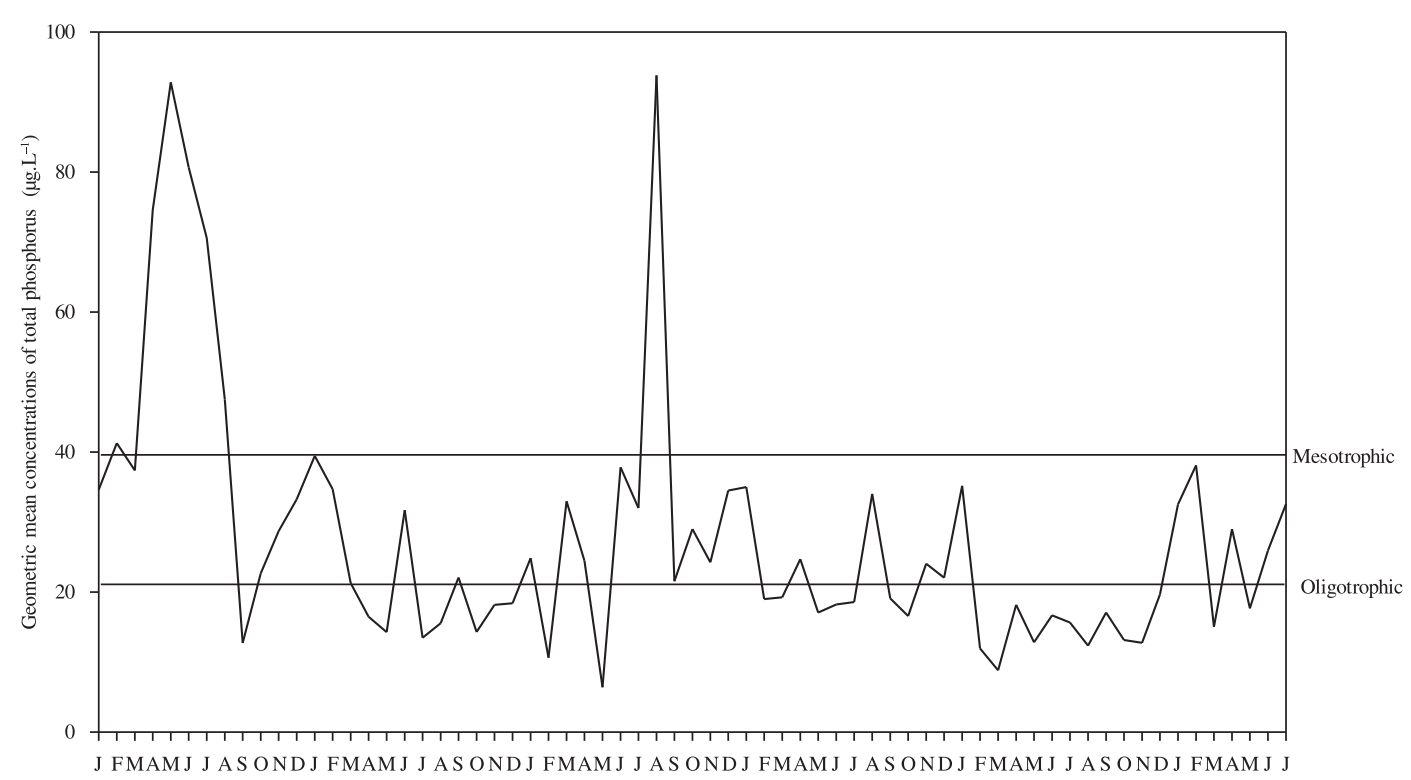

Figure 3. Geometric mean concentrations of total phosphorus $(\mu \mathrm{g} / \mathrm{L})$ in Lake Jacaré between 2002 and 2007, with the classification of trophic status (Salas and Martino, 1991).

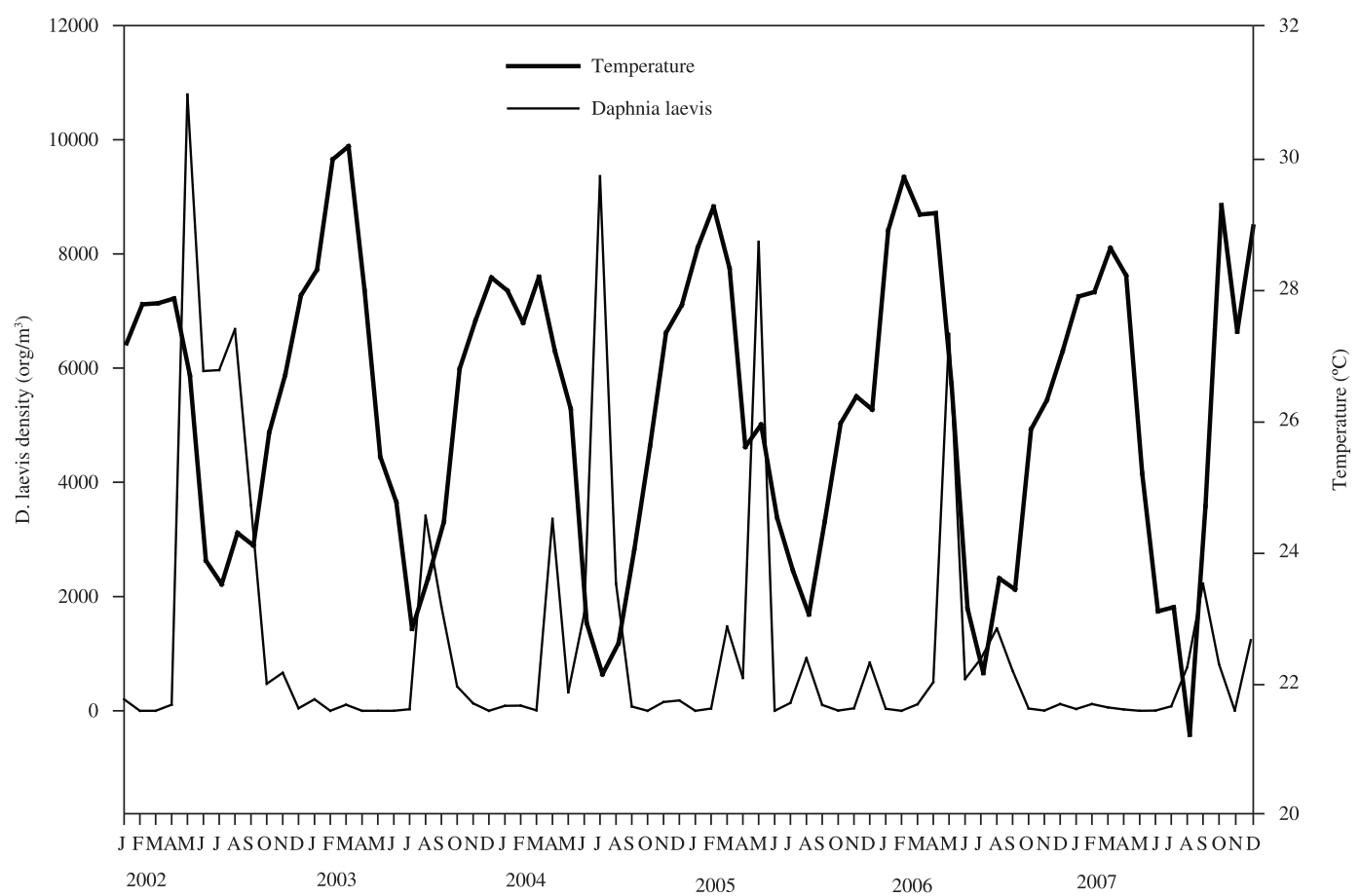

Figure 4. Monthly fluctuations of Daphnia laevis population and mean temperature between 2002 and 2007.

$\mathrm{p}=0.0001)$ and chlorophyll- $a(\mathrm{r}=-0.32$ and $\mathrm{p}=0.016)$, and positive with the lake's trophic state $(r=0.36$ and $p$ $=0.003)$ and total phosphorus $(\mathrm{r}=0.32$ and $\mathrm{p}=0.007)$.

The population density of Chaoborus varied from 0 to 4050 org. $\mathrm{m}^{-3}$, showing positive correlation with $D$. laevis densities $(\mathrm{r}=0.43$ and $\mathrm{p}=0.002)$ (see Tables 1 and 2) (Figure 5).
The differences in D. laevis densities between the dry and rainy seasons were statistically significant $(\mathrm{p}<0.001$, Mann-Whitney test), indicating the effective population increase in the dry seasons, during the lake circulation (Figure 6).

In the sediment collected in October and December 2007 , ephippia of $D$. laevis occurred in densities varying from one to six ephippia. $\mathrm{cm}^{-3}$. 


\section{Discussion}

A clear seasonal pattern for Daphnia laevis in Lake Jacaré was found, with a consistent increase in the population during the circulation periods. This population was greatly influenced by the annual temperature fluctuation during the six years of study. The amount of total phosphorus, the food availability (based on chlorophyll- $a$ ) and the Chaoborus' population also demonstrated an effective influence on the fluctuation of this species in the lake.

Temperature is an important environmental factor affecting zooplankton communities. It is well-known that the increase in temperature can reduce the generation time and life cycle of several organisms, as well as increase the reproduction and filtration rates of many species (Edmondson, 1965; Rocha et al., 1990; Bunioto and Arcifa, 2007). However, a negative correlation between the D. laevis density and temperature was observed in Lake Jacaré, indicating that the natural fluctuation of this species can also be widely influenced by changes in water temperature, even if in a thermal range considered suitable for tropical cladocerans. In a study about the occurrence of species of Daphnia in tropical African lakes, Mergeay et al. (2006) found a relationship between the presence of Daphnia and higher altitudes (mostly from 1,700 to $2,300 \mathrm{~m}$ ) and lower temperatures. According to these authors, the abundance of $D$. laevis decreased with increases in the temperature.
The effect of temperature in temperate environments is clear, affecting the populations directly, and has a recognized importance in zooplankton dynamics (Calaban and Makarewicz, 1982; Korpelainen, 1986; Chen and Folt, 1996; Benndorf et al., 2001; Gerten and Adrian, 2002; Schalau et al., 2008). However, in tropical environments, these effects may not be easily detected. In Lake Jacaré, the effects of temperature on the D. laevis' population were related to the periods of stratification and water column circulation. The increase in this species' population occurred consistently during the dry seasons (mixing period) demonstrating a relationship with water circulation.

The period of water-column mixing has a decisive role in the dynamics of plankton communities. During this period, the disappearance or decrease in the thermocline homogenizes the water column, facilitating the redistribution of zooplankton through it (Thackeray et al., 2006). Furthermore, nutrients become more homogeneously distributed, becoming available to phytoplankters in the euphotic zone. These events lead to an increase in phytoplankton biomass and availability of resources for the zooplankton community (Schelske et al. 1995; Weithoff et al., 2000). A study by Henry et al. (1997) in Lake Jacaré in 1985 and 1987 demonstrated a threefold increase in the primary production of phytoplankton during winter (dry season), when the lake was completely unstratified, leading to the conclusion that an effective process of nutrient mixing and entrance into the euphotic zone occurred during this period. The circulation period also increases the physical space available for the

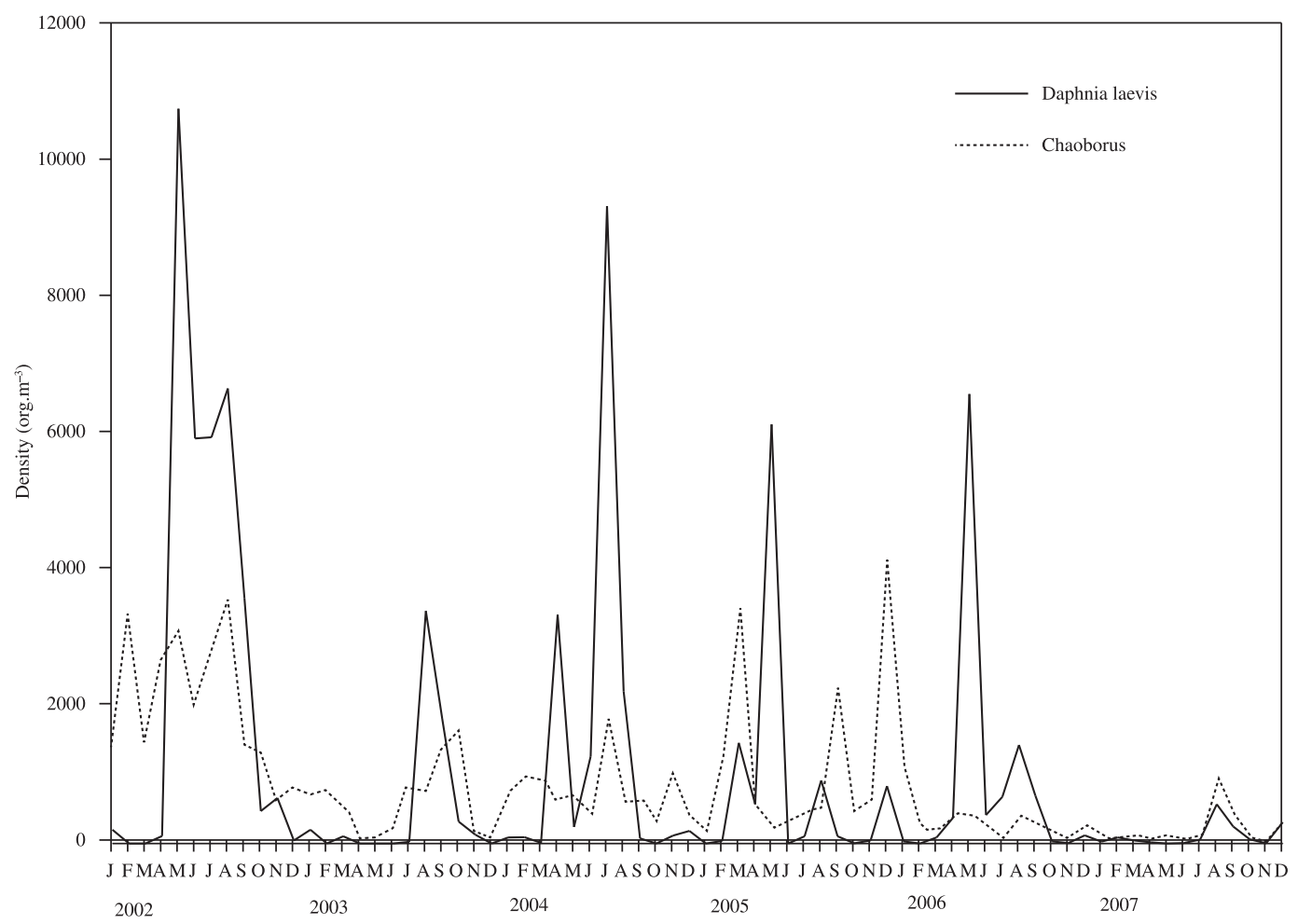

Figure 5. Population fluctuations of Chaoborus and Daphnia laevis between 2002 and 2007. 
species, erasing physical and chemical barriers and allowing dissolved oxygen to enter the deepest layers, which may be uninhabited during the stratification period (Cáceres and Tessier, 2003).

During the thermal stratification periods (rainy season) D. laevis appeared in low densities or almost disappeared from the water column. This can be explained by several factors, such as: a possible greater influence of predation during rainy seasons, higher amounts of solids suspended by turbulence caused by summer rains (Bunioto and Arcifa, 2007), intra and interspecific competition, food availability and quality (Pinto-Coelho et al., 2003), physical and chemical barriers, and lower availability of refuges due to the low do or its depletion in the deepest layers of the lake. Furthermore, during thermal stratification, the organisms tend to aggregate in a certain layer of the water column, where the temperature is favorable to their growth and development, effectively decreasing the available space (Kessler and Lampert, 2004) and thus decreasing the population densities.

The densities of $D$. laevis also showed a significant positive correlation with total phosphorus and trophy. Cladocerans can use not only algae, but also bacteria and detritus, increasing their densities during enrichment periods. Pinto-Coelho (1998) observed a significant and positive relationship between total phosphorus and D. laevis in Lake Pampulha (Belo Horizonte, Minas Gerais, Brazil), where the increase of carbon particles, total phosphorus and total nitrogen were identified as species-density regulating factors. According to Eskinazi-Sant'Anna et al. (2002), during the population peaks of D. laevis in Lake Pampulha, the proportion of amorphous material in the digestive tract of individuals of this species increased considerably, reaching $75 \%$ of the total ingested, whereas in other periods, this material contributed less than $15 \%$. Subsequently, Pinto-Coelho et al. (2003) observed that the eutrophication of Lake Pampulha decreased the food quality (algae) and was a key factor in the collapse of the D. laevis population.

Biotic factors, such as food availability, are also essential to take into account in studies of fluctuation of the population. Several species of Daphnia are recognized as efficient herbivores (Dodson, 1974). The negative correlation between $D$. laevis and chlorophyll- $a$ emphasizes the herbivory pressure of this cladoceran on the phytoplankton community. The availability and quality of food directly affect the reproductive index of a species (Pinto-Coelho et al., 2003; Ruckert and Giani, 2008), and are important controlling factors for population density.

Predation may also be an important factor regulating D. laevis density in Lake Jacaré. Large cladocerans such as Daphnia are not adapted to living in the presence of vertebrate predators, and rapidly disappear in lakes where planktivorous fish are introduced (Brooks and Dodson, 1965). Introduced piscivorous fishes, such as the Piranha Pygocentrus nattereri and the Tucunaré Cichla spp., can exert different pressures on the zooplankton: directly predating as larvae, and indirectly by disrupting other links of the food chain. However, predation by larvae in the limnetic zone is highly unlikely, since the larvae are much more numerous near-shore., In a study on the lakes of the middle River Doce valley, Pinto-Coelho et al. (2008) observed an increase in Chaoborus density caused by the introduction of exotic piscivorous fish species into the lakes. According to the authors, the introduction of these species led to the collapse of the native planktivorous fish species and to the reduction of predation pressure on invertebrates, causing an increase in their density and, thus, an increase in the pressure on other zooplankton organisms by chaoborids. Even in low densities, invertebrate predators can change the structure of the zooplankton community by predating mainly on cladocerans (Rocha et al., 1990). Increases and decreases in the populations of Chaoborus sp. and D. laevis in Lake Jacaré occurred during the same period (or were

Table 2. Spearman correlations (r) for Daphnia laevis mean density and environment variables. Boldface indicates values with significant correlations $(\mathrm{p}<0.05)$.

\begin{tabular}{lrc}
\hline \multicolumn{1}{c}{ Variables } & r & p \\
\hline Temperature & $\mathbf{- 0 . 4 7}$ & $\mathbf{0 . 0 0 0}$ \\
pH & -0.11 & 0.335 \\
Electric conductivity & -0.09 & 0.447 \\
dissolved oxygen & -0.08 & 0.496 \\
Chlorophyll- $\boldsymbol{a}$ & $-\mathbf{0 . 3 2}$ & $\mathbf{0 . 0 1 6}$ \\
Total phosphorus & $\mathbf{0 . 3 2}$ & $\mathbf{0 . 0 0 7}$ \\
phosphate & -0.08 & 0.518 \\
total nitrogen & -0.00 & 0.961 \\
nitrate & 0.01 & 0.928 \\
nitrite & -0.16 & 0.184 \\
ammonia & -0.01 & 0.896 \\
Trophic state & $\mathbf{0 . 3 6}$ & $\mathbf{0 . 0 0 3}$ \\
Chaoborus & $\mathbf{0 . 4 3}$ & $\mathbf{0 . 0 0 2}$ \\
\hline
\end{tabular}

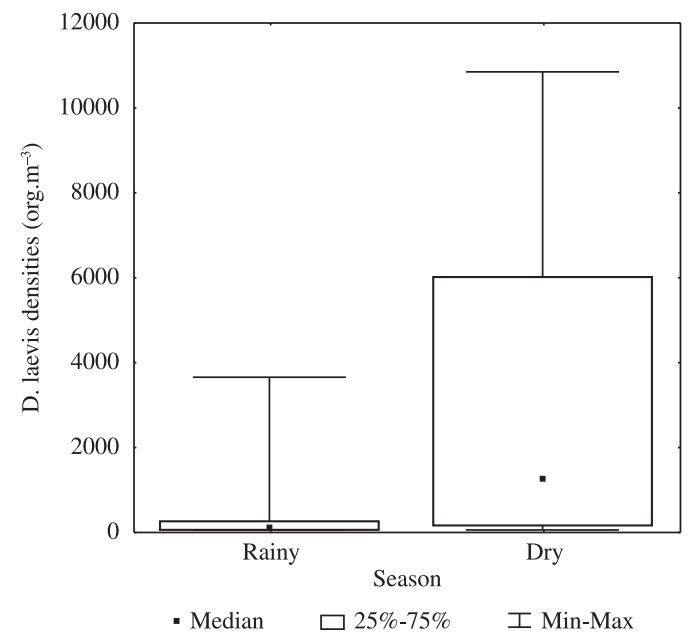

Figure 6. Mean densities of Daphnia laevis in the pooled dry and rainy periods between 2002 and 2007. 
coincident), which suggests that there is a relationship between both populations. A study being developed in this lake on the diet of Chaoborus sp. has been showing the intake of Daphnia by these invertebrate (Alfenas, unpublished data). Invertebrate predators other than larvae of Chaoborus (Mesostoma and Acari) were also observed in Lake Jacaré.

Peaks in the population of $D$. laevis may also be related to the hatching of ephippia. In a study of ephippia of $D$. laevis in Lake Jacaré, it was observed that the higher hatching rates of ephippia occur in circulation periods (Brandão, 2009), suddenly increasing the population size. In tropical systems, there is evidence that temperature is one of the main stimulating factors of production and hatching of dormant stages (Crispim and Watanabe, 2000).

Our results indicate that changes in physical and chemical characteristics of water during stratification and circulation of the lake can directly influence (temperature, total phosphorus) or indirectly (food availability, presence of predators, hatching of ephippia) the population dynamics of D. laevis.

Acknowledgments - This work was supported by Conselho Nacional de Desenvolvimento Científico e Tecnológico (CNPq) and Fundação de Amparo a Pesquisa do Estado de Minas Gerais (FAPEMIG). We would like to thank the Laboratory of Ecology of Zooplankton of the Federal University of Minas Gerais and the entire staff of the Brazilian Long-Term Ecological Research (LTER/UFMG) coordinated by Prof. Dr. Francisco Barbosa, UFMG.

\section{References}

BARROS, LS., AMARAL, LA. and LORENZON, CS., 2007. Uso de Daphnia magna como bioindicador da poluição gerada por efluentes de abatedouros de aves e suínos. Revista Brasileira de Saúde e Produção Animal, vol. 8, no. 3.

BENNDORF, J., KRANICH, J., MEHNER, T. and WAGNER, A., 2001. Temperature impact on the midsummer decline of Daphnia galeata: An analysis of long-term data from the biomanipulated Bautzen Reservoir (Germany). Freshwater Biology, vol. 46, p. 199-211. http://dx.doi.org/10.1046/j.1365-2427.2000.00657.x

BOTTRELL, HH., 1975. The relationship between temperature and duration of egg development in some epiphytic Cladocera and Copepoda from the River Thames, reading, with a discussion of temperature functions. Oecologia, vol. 18, p. 63-84.

BRANDÃO, LPM., 2009. Efípios de Daphnia laevis em lago permanente tropical: mecanismo de resiliência a alterações ambientais? Belo Horizonte: Universidade Federal de Minas Gerais. Dissertação de Mestrado em Ecologia.

BROOKS, JL. and DODSON, SI., 1965. Predation, body size, and composition of plankton. Science, vol. 150, p. 28-35. PMid:17829740. http://dx.doi.org/10.1126/science.150.3692.28

BUNIOTO, TC. and ARCIFA, MS., 2007. Effects of food limitation and temperature on cladocerans from a tropical Brazilian lake. Aquatic Ecology, vol. 41, p. 569-578. http://dx.doi.org/10.1007/ s10452-007-9114-2

CÁCERES, CE. and TESSIER, AJ., 2003. How long to rest: The ecology of the optimal dormancy and environment constraint.
Ecology, vol. 84, no. 5, p. 1189-1198. http://dx.doi.org/10.1890/00129658(2003)084[1189:HLTRTE]2.0.CO;2

CALABAN, MJ. and MAKAREWICZ, JC., 1982. The effect of temperature and density on the amplitude of vertical migration of Daphnia magna. Limnology and Oceanography, vol. 27, p. 262-271. http://dx.doi.org/10.4319/1o.1982.27.2.0262

CHEN, CY. and FOLT, CL., 1996. Consequences of fall warming for zooplankton overwintering success. Limnology and Oceanography, vol. 41, p. 1077-1086. http://dx.doi.org/10.4319/lo.1996.41.5.1077

CRISPIM, MC. and WATANABE, T., 2000. Ovos de resistência de rotíferos presentes em sedimentos secos de um açude no semiárido paraibano. Acta Limnologica Brasiliensia, vol. 12, p. 89-94.

DODSON, SI., 1974. Zooplankton competition and predation: and experimental test of the size efficiency hypothesis. Ecology, vol. 55, p. 605-613. http://dx.doi.org/10.2307/1935150

DODSON, SI. and FREY, DG., 1991. Cladocera and other Branchiopoda. In THORP, JH. and COVICH, AP. (Eds.). Ecology and classification of North American freshwater invertebrates. San Diego: Academic Press. p. 723-786.

EDMONDSON, WT., 1965. Reproductive rate of planktonic rotifers as related to food and temperature in nature. Ecological Monographs, vol. 35, p. 61-111. http://dx.doi.org/10.2307/1942218

ESKINAZI-SANT'ANNA, EM., MAIA-BARBOSA, PM. and BARBOSA, FAR., 2002. On the natural diet of Daphnia laevis in the eutrophic Pampulha reservoir (Belo Horizonte, Minas Gerais). Revista Brasileira de Biologia = Brazilian Journal of Biology, vol. 62, no. 3, p. 445-452. http://dx.doi.org/10.1590/ S1519-69842002000300007

FRYER, G., 1996. Diapause, a force in the evolution of freshwater crustaceans. Hydrobiologia, vol. 320, p. 1-14. http://dx.doi. org/10.1007/BF00016800

GERTEN, D. and ADRIAN, R., 2002. Species-specific changes in the phenology and peak abundance of freshwater copepods in response to warm summers. Freshwater Biology, vol. 47, p. 2163-2173. http://dx.doi.org/10.1046/j.1365-2427.2002.00970.x

GYLLSTRÖM, M. and HANSSON, L.A., 2004. Dormancy in freshwater zooplankton: Induction, termination and the importance of benthic-pelagic coupling. Aquatic Science, vol. 66, no. 1, p. 274-295. http://dx.doi.org/10.1127/0003-9136/2004/0161-0081

HENRY, R., TUNDISI, JG., CALIJURI, MC. and IBAÑEZ, MSR., 1997. A comparative study of thermal, heat content and stability of stratification lakes. In TUNDISI, JG. and SAIJO, Y. (Eds.). Limnological Studies on the Rio Doce Valley Lakes, Brazil. Rio de Janeiro: BAS, USP, CWRAE.

KESSLER, K. and LAMPERT, W., 2004. Fitness optimization of Daphnia in a trade-off between food and temperature. Oecologia, vol. 140, p. 381-387. PMid:15197642. http://dx.doi.org/10.1007/ s00442-004-1592-5

KORPELAINEN, H., 1986. The effects of temperature and photoperiod on life history parameters of Daphnia magna (Crustacea: Cladocera). Freshwater Biology, vol. 16, p. 615-620. http://dx.doi.org/10.1111/j.1365-2427.1986.tb01004.x

LATINI, AO., LIMA-JUNIOR, DP., GIACOMINI, HC., LATINI, RO., RESENDE, DC., ESPÍRITO-SANTO, HMV., BARROS, DF. and PEREIRA, TL., 2004. Alien fishes in lakes of the Doce river basin (Brazil): range, new occurrences and conservation of native communities. Lundiana, vol. 5, no. 2, p. 135-142. 
LYNCH, M., 1980. The evolution of cladoceran life histories. Quarterly Review of Biology, vol. 55, p. 23-42. http://dx.doi. org/10.1086/411614

LORENZEN, CJ., 1967. Determination of chlorophyll and pheo-pigments: spectrophotometric equations. Limnology and Oceanography, vol. 12, p. 343-346. http://dx.doi.org/10.4319/ 1o.1967.12.2.0343

MAcKERETH, FJH., HERON, J. and TALLING, JF., 1978. Water analysis and some revised methods for limnologists. New York: Freshwater Biological Association. vol. 36, 120 p.

MAIA-BARBOSA, PM., ESKINAZI-SANT'ANNA, EM. and BARBOSA, FAR., 2003a. Zooplankton composition and vertical distribution in a tropical, monomictic Lake (Dom Helvécio Lake, Southeastern Brazil). Acta Limnologia Brasiliensia, vol. 15, no. 1 , p. 65-74.

MAIA-BARBOSA, PM., ESKINAZI-SANT'ANNA, E., VALADARES, CF. and PESSOA, GCD., 2003b. The resting eggs of zooplankton from a tropical, Eutophic Reservoir (Pampulha Reservoir, South-East Brazil). Lakes and Reservoirs: Research and Management, vol. 8, p. 269-275. http://dx.doi.org/10.1111/j.14401770.2003.00229.x

MARCUS, NH., 1990. Calanoid copepod, cladoceran, and rotifer eggs in sea-bottom sediments of northern Californian coastal waters: identification, occurrence and hatching. Marine Biology, vol. 105, p. 413-418. http://dx.doi.org/10.1007/BF01316312

MERGEAY, J., DECLERCK, S., VERSCHUREN, D. and DE MEESTER, L., 2006. Daphnia community analysis in shallow Kenyan lakes and ponds using dormant eggs in surface sediments. Freshwater Biology, vol. 51, p. 399-411. http://dx.doi. org/10.1111/j.1365-2427.2005.01494.x

ONBÉ, T., 1978. Sugar floatation method for sorting the resting eggs of marine cladocerans and copepods from sea bottom sediment. Bulletin of the Japanese Society for the Science of Fish, vol. 44, p. 1141. http://dx.doi.org/10.2331/suisan.44.1141

PINTO-COELHO, RM., 1998. Effects of eutrophication on seasonal patterns of mesozooplankton in a tropical reservoir: a 4-year study in Pampulha Lake, Brazil. Freshwater Biology, vol. 40, p. 159-173. http://dx.doi.org/10.1046/j.1365-2427.1998.00327.x

PINTO-COELHO, RM., BEZERRA-NETO, JF., GIANI, A. MACEDO, CF., FIGUEIREDO, CC. and CARVALHO, EA., 2003. The collapase of a Daphnia laevis Birge, 1878 population in Pampulha Reservoir, Brazil. Acta Limnologica Brasiliensia, vol. 15, no. 3, p. 53-70.

PINTO-COELHO, RM., BEZERRA-NETO, JF., MIRANDA, F., MOTA, TG., SANTOS, AM., MAIA-BARBOSA, PM., MELLO, N. MARQUES, MM., CAMPOS, M. and BARBOSA, FAR., 2008.
The inverted trophic cascade in tropical plankton communities: impacts of exotic fish in the Middle Rio Doce lake district, Minas Gerais, Brazil. Revista Brasileira de Biologia $=$ Brazilian Journal of Biology, vol. 68, p. 631-637.

ROCHA, O., MATSUMURA-TUNDISI, T. TUNDISI, JG. and FONSECA, CP., 1990. Predation on and by pelagic Turbellaria in some lakes in Brazil. Hydrobiologia, vol. 198, p. 91-101. http:// dx.doi.org/10.1007/BF00048625

RUCKERT, G. Von and GIANI, A., 2008. Biological interactions in the plankton community of a tropical eutrophic reservoir: is the phytoplankton controlled by zooplankton? Journal of Plankton Research, vol. 30, no.10, p. 1157-1168. http://dx.doi.org/10.1093/ plankt/fbn065

SALAS, H. and MARTINO, P., 1991. A simplified phosphorus trophic state model for warm-water tropical lakes. Water Research, vol. 25, no. 3, p. 341-350. http://dx.doi.org/10.1016/00431354(91)90015-I

SCHALAU, K., RINKE, K., STRAILE, D. and PEETERS, F., 2008. Temperature is the key factor explaining interannual variability of Daphnia development in spring: a modelling study. Oecologia, vol. 157, p. 531-543. PMid:18574598. http://dx.doi. org/10.1007/s00442-008-1081-3

SCHELSKE, CL., CARRICK, HJ. and ALDRIDGE, FJ., 1995. Can wind-induced resuspension of meroplankton affect phytoplankton dynamics? Journal of the North American Benthological Society, vol. 14, p. 616-630. http://dx.doi.org/10.2307/1467545

SMITH, DW. and COOPER, SD., 1982. Competition among Cladocera. Ecology, vol. 63, no. 4, p. 1004-1015. http://dx.doi. org/10.2307/1937240

THACKERAY, SJ., GEORGE, DG., JONES, RI. and WINFIELD, IJ., 2006. Statistical quantification of the effect of thermal stratification on patterns of dispersion in a freshwater zooplankton community. Aquatic Ecology, vol. 40, p. 23-32. http://dx.doi. org/10.1007/s10452-005-9021-3

VIJVERBERG, J., KALF, DF. and BOERSMA, M., 1996. Decrease in Daphnia egg viability at elevated pH. Limnology and Oceanography, vol. 41, p. 789-794. http://dx.doi.org/10.4319/ 1o.1996.41.4.0789

WEITHOFF, G., LORKE, A. and WALZ, N., 2000. Effects of water-column mixing on bacteria, phytoplankton, and rotifers under different levels of herbivory in a shallow eutrophic lake. Oecologia, vol. 125, p. 91-100. http://dx.doi.org/10.1007/PL00008896

WILLIAMS, JB., 1982. Temporal and spatial patterns of abundance of the Chydoridae (Cladocera) in Lake Itasca, Minnesota. Ecology, vol. 63, no. 2, p. 345-353. http://dx.doi.org/10.2307/1938952 
